\title{
Effect of Salt on a Thermosensitive Mutant of Bacillus subtilis Deficient in Uracil and Cell Division
}

\author{
Nobuyoshi Miyazaki, Kazuo Nagai and Gakuzo Tamura \\ Department of Agricultural Chemistry, University of Tokyo \\ Received June 28, 1976
}

\begin{abstract}
A thermosensitive uracil requiring mutant of Bacillus subtilis Marburg 168 thy $\operatorname{trp}_{2}$ ts 42 was examined as to the colony forming ability at the permissive and nonpermissive temperatures. The viability of the mutant cells decreased rapidly at the restrictive temperature in the modified Woese's (MW) medium. However, the cells retained viability when sodium succinate or potassium chloride was added to the medium at that temperature although uracil deficiency was unchanged. A little but significant incorporation of adenine- $8{ }^{14} \mathrm{C}$ into RNA still continued even after the incorporation of $\mathrm{N}$-acetyl- ${ }^{3} \mathrm{H}$-D-glucosamine into acid insoluble fraction of the cells terminated in the MW medium at $48^{\circ} \mathrm{C}$. Both incorporations as well as increase of absorbance were slowed down in the presence of sodium succinate at $48^{\circ} \mathrm{C}$. This mutant, ts 42, was more sensitive to deoxycholate (DOC) than the parent strain. The restoration of colony forming ability after the temperature shift back from 48 to $37^{\circ} \mathrm{C}$ was suppressed by the addition of DOC to the medium. However, the cell became resistant to DOC when uracil was added to the medium prior to the temperature shift.
\end{abstract}

In a preceding paper, ${ }^{11}$ a thermosensitive mutant of Bacillus subtilis, ts 42 , is shown to form filament and lose viability at $48^{\circ} \mathrm{C}$ and rapidly restore colony forming ability when temperature is shifted back to $37^{\circ} \mathrm{C}$ or uracil is added to the medium at $48^{\circ} \mathrm{C}$. These observations suggest that uracil deficiency of this mutant at the restrictive temperature causes unbalance of intracellular material and cell surface because uracil participates both metabolic pathways synthesizing protein through RNA and cell envelope through UDPsugars. $^{2 \sim 4}$ Therefore, it is investigated whether such unbalance is the case in the present mutant and the colony forming ability is restored by the addition of salt which increases osmotic pressure of the medium. Many of the temperature sensitive mutants including division mutants have been reported to be thermoresistant when salts are introduced to the medium at the nonpermissive temperature. ${ }^{5 \sim 10)}$ It is found that the loss of viability of the present mutant ts 42 at $48^{\circ} \mathrm{C}$ is completely suppressed by addition of sodium succinate or potassium chloride though filament formation and uracil deficiency are un- changed.

\section{MATERIALS AND METHODS}

Cell growth. A wild-type strain Bacillus subtilis Marburg 168 thy trp $p_{2}$ and its thermosensitive uracil requiring derivative, ts 42 , were grown in $\mathrm{MW}$ (modified Woese's) medium and allowed to form colony on an NBT-agar plate. The constituents of the media have been shown in a previous paper. ${ }^{13}$

The cell growth was followed by increase of absorbance at $550 \mathrm{~nm}$ determined by a Spectronic 20 photometer. The total cell number was examined by a Coulter Counter as described previously. ${ }^{1)}$

Syntheses of RNA and envelope fraction. The incorporation of adenine- $8-{ }^{14} \mathrm{C}$ into RNA or $\mathrm{N}$-acetyl $-{ }^{3} \mathrm{H}$ $\mathrm{D}$-glucosamine into acid insoluble fraction was examined at 37 and $48^{\circ} \mathrm{C}$ with or without addition of sodium succinate. RNA fraction was prepared following the method of Schmidt and Thannhauser ${ }^{11)}$ as described previously. ${ }^{12)}$ In the case of $\mathrm{N}$-acetylglucosamine, $5 \mu \mathrm{Ci}$ of tritiated compound with $100 \mu \mathrm{g}$ of cold one were added to $10 \mathrm{ml}$ of an exponentially growing culture in $\mathrm{MW}$ medium at $37^{\circ} \mathrm{C}$ at a cell density of $4 \% 10^{7} / \mathrm{ml}$. The mixture was divided into three parts. The first one was incubated at $37^{\circ} \mathrm{C}$, the second at $48^{\circ} \mathrm{C}$ and the third was supplemented with $0.3 \mathrm{M}$ of sodium succinate and incubated at $48^{\circ} \mathrm{C}$. At time intervals, $0.25 \mathrm{ml}$ of the suspension was poured into $0.25 \mathrm{ml}$ of $10 \%$ ice-cold trichloroacetic acid. After one hr at $0^{\circ} \mathrm{C}$, the acid 
insoluble fraction was collected by centrifugation and washed twice with $5 \%$ cold trichloroacetic acid and once with ethanol-ether. The precipitate was dissolved in one $\mathrm{ml}$ of $1 \mathrm{~N} \mathrm{NH}{ }_{4} \mathrm{OH}$ and the radioactivity was determined by a liquid scintillation counter.

Determination of minimum growth inhibitory concentration (MIC). MICs of the drugs including detergents, antibiotics, chemical agents and basic dyes were determined by the method of broth dilution. Overnight cultures of $t \$ 42$ and the parent strain in MW medium were diluted 1000 fold with fresh MW medium. The cell growth in the presence of serially diluted drugs was examined turbidmetrically after $48 \mathrm{hr}$ of incubation at $37^{\circ} \mathrm{C}$.

\section{RESULTS}

Effect of sodium succinate on colony forming ability of $t s 42$

An exponentially growing culture of $\mathrm{ts} 42$ at $37^{\circ} \mathrm{C}$ was shifted to $48^{\circ} \mathrm{C}$. The number of

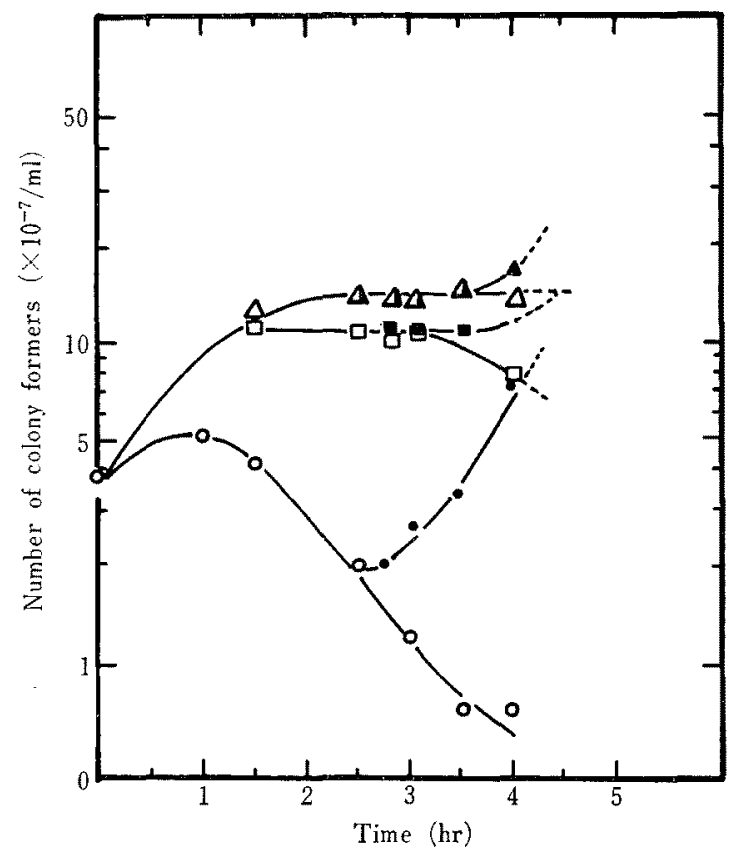

FIG. 1. Number of Total Cells and Colony Formers of $\mathrm{ts} 42$.

An exponentially growing culture of ts 42 at $37^{\circ} \mathrm{C}$ was shifted to $48^{\circ} \mathrm{C}$ at a cell density of $4 \times 10^{7} / \mathrm{ml}$. After $2.5 \mathrm{hr}$ of incubation, uracil $(10 \mu \mathrm{g} / \mathrm{ml})$ was introduced to portions of the culture (closed symbols). At indicated times, cells were withdrawn and allowed to form colonies at $37^{\circ} \mathrm{C}$ on an NBT-agar plate supplemented with $(\square, \square)$ or without $(O, 0) 0.5 \mathrm{M}$ sodium succinate. Total cell number $(\Delta, \Delta)$ was examined by a Coulter Counter. colony formers on an NBT-agar plate supplemented with $0.5 \mathrm{M}$ sodium succinate was compared with total cell number counted by a Coulter Counter (Fig. 1). As described in a preceding paper, ${ }^{11}$ the viable counts on an NBT-agar plate began to decrease after one $\mathrm{hr}$ of incubation at $48^{\circ} \mathrm{C}$. However, when the cells were allowed to form colonies on an NBT. agar plate supplemented with sodium succinate, ${ }^{13)}$ the number of viable cells increased about three times as many as those before the temperature shift within $1.5 \mathrm{hr}$ and remained constant thereafter. The total cell count nearly coincided with the number of colony formers on an NBT-agar plate containing sodium succinate.

When uracil was introduced to the culture after $2.5 \mathrm{hr}$ of incubation at $48^{\circ} \mathrm{C}$, the number of colony formers increased rapidly with little period of lag as described previously. ${ }^{1)}$

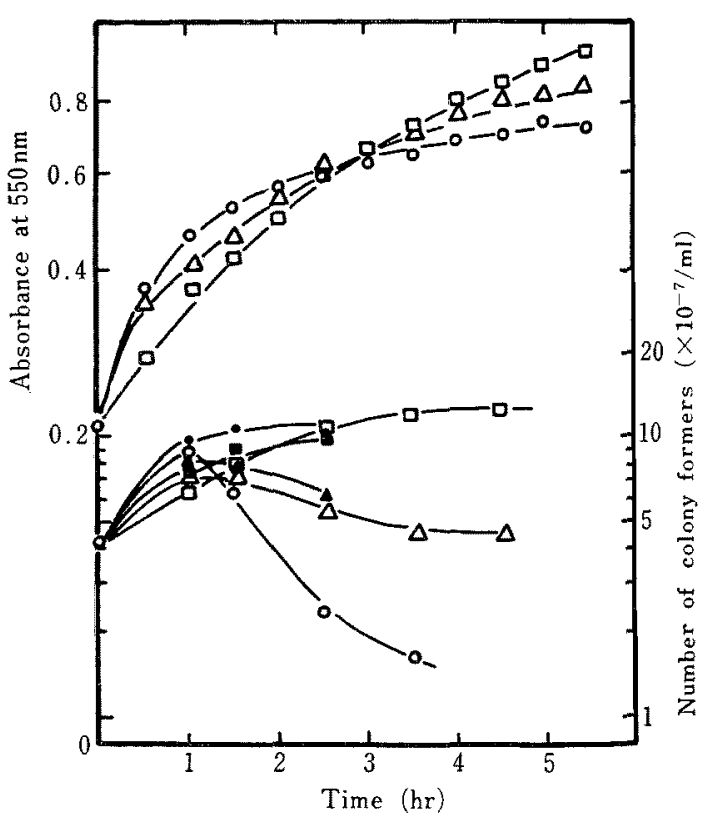

FIg. 2. Effect of Sodium Succinate on Increase of Absorbance and Colony Forming Ability of ts 42 .

An exponentially growing culture of ts 42 at $37^{\circ} \mathrm{C}$ was shifted to $48^{\circ} \mathrm{C}$ at a cell density of $4 \times 10^{7} / \mathrm{ml}$. Sodium succinate was introduced to the medium at the time of the temperature shift. At time intervals, cells were withdrawn and allowed to form colonies on an NBTagar plate supplemented with (closed symbols) or without (open symbols) $0.5 \mathrm{~m}$ sodium succinate.

$\mathrm{O}, \bullet$, control; $\triangle, \wedge, 0.1 \mathrm{M}$ sodium succinate was added; $\square, \mathbf{n}, 0.3 \mathrm{~m}$ sodium succinate was added. 
However, the increase of total cell number was observed only $60 \mathrm{~min}$ after addition of uracil. The results suggested that the rapid increase of viability after the introduction of uracil was mainly resulted from restoration of colony forming ability by the cells already present at the time of uracil addition and not from the rapid production of newborn cells.

It was examined whether sodium succinate could protect ts 42 cells in MW medium at $48^{\circ} \mathrm{C}$ from losing colony forming ability on an NBT-agar plate. As shown in Fig. 2, the increase of absorbance was slowed down in the presence of $0.3 \mathrm{M}$ sodium succinate but the cells could form colony on an NBT-agar plate as well as that supplemented with sodium succinate. The loss of viability was significantly reduced even by addition of only $0.1 \mathrm{M}$ sodium succinate to the MW medium. Therefore, an appropriate concentration of sodium succinate either in MW medium or an NBTagar plate was effective in making cells of ts 42 retain viability. An optimal concentration of sodium succinate in MW medium was found to be $0.3 \mathrm{M}$. The increase of absorbance was suppressed or the number of colony formers reduced at either concentrations more or less than $0.3 \mathrm{M}$.

Similar results were obtained when potassium chloride was added to the MW medium at $48^{\circ} \mathrm{C}$ in place of sodium succinate although optimal concentration was different. Therefore, it is plausible that the effect of sodium succinate is brought about not by sodium or succinate ion but as a salt which may influence the osmotic condition of the medium.

\section{Syntheses of RNA and materials containing $N$-acetylglucosamine}

The elongation and loss of viability of ts 42 at $48^{\circ} \mathrm{C}$ were suggested to be derived from uracil deficiency in the pathways including formation of cell wall, septum or envelope other than RNA. As described above, loss of colony forming ability of the mutant at $48^{\circ} \mathrm{C}$ was suppressed by addition of sodium succinate or potassium chloride. Therefore, the syntheses of RNA and envelope fraction were

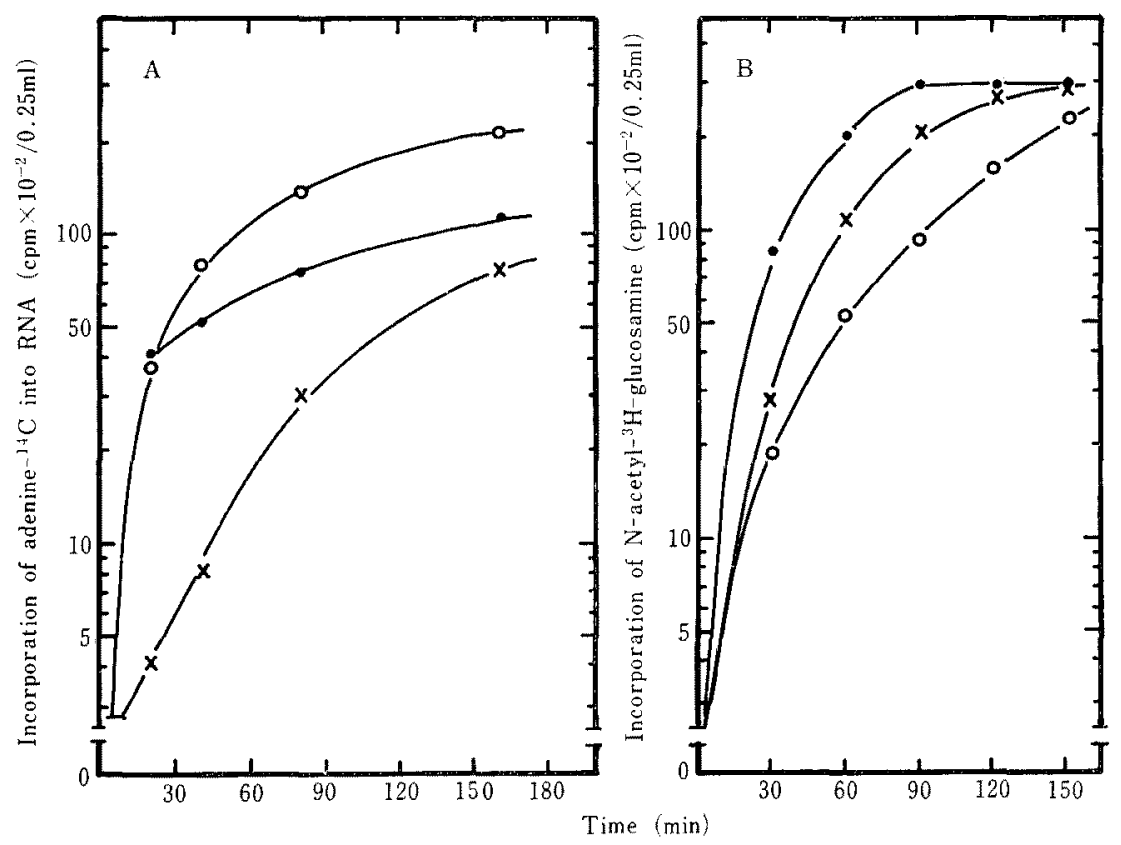

FIG. 3. Incorporation of Adenine into RNA (A) and N-Acetylglucosamine into Acid Insoluble Fraction (B).

$\mathrm{O}, 37^{\circ} \mathrm{C}$ in $\mathrm{MW}$ medium;, $48^{\circ} \mathrm{C}$ in $\mathrm{MW}$ medium; $x, 48^{\circ} \mathrm{C}$ in $\mathrm{MW}$ medium containing $0.3 \mathrm{M}$ sodium succinate. 
examined in the presence and absence of sodium succinate using radioactive adenine and $\mathrm{N}$-acetylglucosamine as indicators (Fig. 3).

The rate of incorporation of adenine $-8{ }^{14} \mathrm{C}$ into RNA fraction was shown to be identical both at 37 and $48^{\circ} \mathrm{C}$ in initial $20 \mathrm{~min}$ and slowed down thereafter at $48^{\circ} \mathrm{C}$ in $\mathrm{MW}$ medium. However, significant increase of RNA was observed until $160 \mathrm{~min}$. The uptake of adenine- $8-{ }^{14} \mathrm{C}$ was not so rapid in the medium supplemented with sodium succinate and normally proceeded for $160 \mathrm{~min}$ at $48^{\circ} \mathrm{C}$. In contrast to the case of RNA, the incorporation of $\mathrm{N}$-acetyl $-{ }^{3} \mathrm{H}$-glucosamine into acid insoluble fraction of the mutant terminated within $90 \mathrm{~min}$ at $48^{\circ} \mathrm{C}$ in the $\mathrm{MW}$ medium. This coincided with the time when the loss of viability of the cells initiated. Gradual increase of $\mathrm{N}$-acetylglucosamine uptake by the cells at $48^{\circ} \mathrm{C}$ in the medium enriched with sodium succinate was shown until 120 min when it reached the maximal level observed in MW medium.

\section{Drug sensitivity of $t \$ 42$ and the parent strain}

It has been reported that some bacteria defective in peptideglycan layer are sensitive to detergents. ${ }^{9,14)}$ As the present mutant ts42 elongated and became labile to osmotic conditions at $48^{\circ} \mathrm{C}$, some abnormality of cell surface could be expected. Therefore, MIC of drugs against ts 42 was compared with the case of the parent strain by the broth dilution method. Among the detergents tested, deoxycholate was found to be two to four times more effective on the mutant than on the parent (Table I). However, the MICs of following agents against the mutant was comparable to that against the parent; inhibitors of DNA synthesis, mitomycin C and bleo-

Table I. Minimum Growth Inhibitory Concentrations of Detergents aGaInst the Parent Strain and ts 42

\begin{tabular}{lcc}
\hline \multicolumn{1}{c}{ Detergent } & Parent & ts 42 \\
\hline Sodium lauryl sulfate & $75 \mu \mathrm{g} / \mathrm{ml}$ & $75 \mu \mathrm{g} / \mathrm{ml}$ \\
Deoxycholate & 300 & $75 \sim 150$ \\
Triton X-100 & 150 & 150 \\
\hline
\end{tabular}

mycin $\mathrm{A}_{2}$; inhibitors of RNA synthesis, rifampicin and streptolydigin; inhibitors of protein synthesis, kanamycin, streptomycin and chloramphenicol; drugs affecting cell surface, colistin, polymyxin, tunicamycin, cycloserine and penicillin $\mathrm{G}$; basic dyes, malachite green and methylene blue.

\section{Effect of deoxycholate on colony forming ability of $t s 42$}

An exponentially growing culture of $t \leqslant 42$ at $37^{\circ} \mathrm{C}$ was shifted to $48^{\circ} \mathrm{C}$ and divided into three parts. All of them were shifted back to $37^{\circ} \mathrm{C}$ after $75 \mathrm{~min}$ of incubation at $48^{\circ} \mathrm{C}$. Final concentration of $10 \mu \mathrm{g} / \mathrm{ml}$ of uracil was added to the second part $5 \mathrm{~min}$ prior to the temperature shift back but not to the third one. Deoxycholate $(48 \mu \mathrm{g} / \mathrm{ml})$ was introduced into both second and third parts at the time of temperature shift back. The number of colony formers were examined and the result is presented in Fig. 4. When the culture was shifted back to $37^{\circ} \mathrm{C}$ without deoxycholate, the first part, rapid increase of viable count was shown after $10 \mathrm{~min}$ of lag. On the other

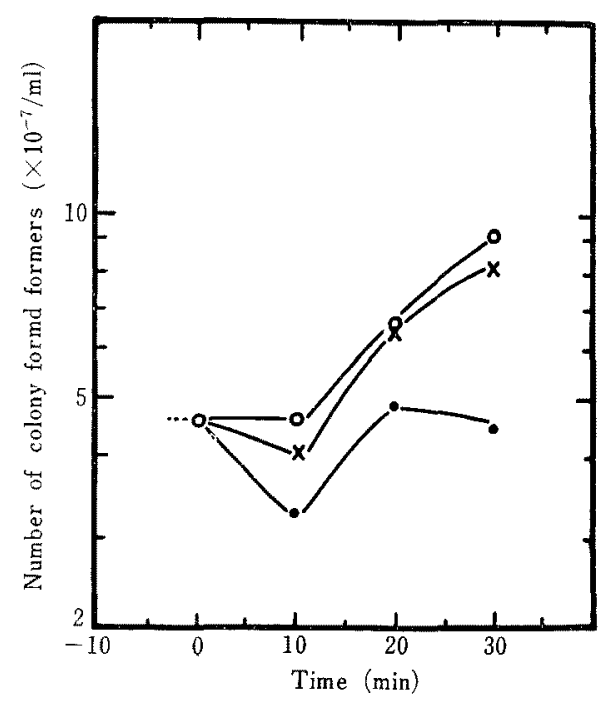

FIG. 4. Effect of Deoxycholate on Cell Viability of ts42.

After incubation at $48^{\circ} \mathrm{C}$ for $75 \mathrm{~min}$, cells were shifted back to $37^{\circ} \mathrm{C}$ (time 0 ), with $(\Theta, x)$ or without $(0)$ addition of deoxycholate $(48 \mu \mathrm{g} / \mathrm{ml})$. Uracil $(10$ $\mu \mathrm{g} / \mathrm{ml}$ ) was introduced to a portion of the culture $(\mathrm{x})$ 5 min prior to the temperature shift back. 
hand, when shifted back to $37^{\circ} \mathrm{C}$ with addition of deoxycholate, the viable count decreased and then resumed to the value before the shift but failed to increase thereafter. When the culture was shifted to $37^{\circ} \mathrm{C}$ after addition of uracil, increase of viable count was similar to that without uracil even in the presence of deoxycholate.

\section{DISCUSSION}

It has been reported that a mutant of Bacillus subtilis, ts 42 , requires uracil for growth, forms filaments and loses colony forming ability at $48^{\circ} \mathrm{C}$ and rapidly restores viability when shifted back to $37^{\circ} \mathrm{C}$. ${ }^{1}$ In the present results, it was shown when the mutant cells were shifted from 37 to $48^{\circ} \mathrm{C}$ in $\mathrm{MW}$ medium, the incorporation of $\mathrm{N}$-acetyl- ${ }^{3} \mathrm{H}$-glucosamine, a typical component of cell envelope, ${ }^{2 \sim 4)}$ into acid insoluble fraction terminated earlier than that of adenine $-{ }^{14} \mathrm{C}$ into RNA. The increase of net protein content observed previously $^{1)}$ should be supported by this persistently synthesized RNA and let the cell volume increase after the cell envelope formation was suppressed. Thus, the unbalance in the ratio of intracellular materials to cell surface made the cell elongate and osmotically fragile and caused loss of viability. Therefore, it is plausible that the addition of salt such as sodium succinate or potassium chloride to the medium at $48^{\circ} \mathrm{C}$ protected the cell from such lability by increasing the osmotic pressure of the medium. This kind of salt effect has been reported by several investigators. ${ }^{5 \sim 19}$ Moreover, in case of the present mutant, it has been observed that both incorporations of adenine into RNA and $\mathrm{N}$-acetylglucosamine into acid insoluble fraction at $48^{\circ} \mathrm{C}$ as well as increase of absorbance were slowed down in parallel in the presence of sodium succinate. This slow and balanced increase of both components might be the reason why the mutant cell could retain colony forming ability when spread on an NBT-agar plate without sodium succinate.
The present mutant was a little more sensitive to deoxycholate than the parent strain at $37^{\circ} \mathrm{C}$. This suggests that ts 42 is still partially defective in some cell surface structure although growth and morphology were normal at the permissive temperature. The increase of viability after temperature shift from 48 to $37^{\circ} \mathrm{C}$ was suppressed by addition of deoxycholate to the culture. However, when uracil was introduced to the culture $5 \mathrm{~min}$ prior to the temperature shift, viable count of the cells increased abruptly in the presence of deoxycholate as well as in the absence of the agent. Therefore, the mutant cell restores resistance to deoxycholate provided that uracil is added to the culture at $48^{\circ} \mathrm{C}$.

From above, it is concluded that uracil deficiency of the present mutant, ts42, at the restrictive temperature causes unbalanced growth resulting in filament formation with concomitant loss of viability which can be rescued by the addition of salt to the culture.

Acknowledgment. This work was supported by a Grant from the Ministry of Education, the Japanese Government.

\section{REFERENCES}

1) K. Nagai, H. Some and G. Tamura, Agr. Biol. Chem., 40, 2237 (1976).

2) M. J. Osborn, Ann. Rev. Biochem., 38, 501 (1969).

3) H. J. Rogers, Bacteriol. Rev., 34, 194 (1970).

4) L. Glaser, Amm. Rev. Biochem., 42, 91 (1973).

5) A. Z. Bilsky and J. B. Armstrong, J. Bacteriol., 113, 76 (1973).

6) J. N. Reeve, D. J. Groves and D. J. Clark, ibid., 104, 1052 (1970).

7) M. Inouye, ibid., 99, 842 (1969).

8) H. J. Rogers, M. Mc Connell and I. D. J. Burdett, J. Gent. Microbiol, 61, 155 (1970).

9) A. N. Chattergie and F. E. Young, J. Bacteriol,, 111, 220 (1972).

10) M. Ricard and Y. Hirota, ibid., 116, 314 (1973).

11) G. Schmidt and S. J. Thannhauser, J. Biol. Chem., 161, 83 (1945).

12) K. Nagai and G. Tamura, J. Bacteriol., 112, 959 (1972).

13) N. Anraku and O. E. Landman, ibid., 95, 1813 (1968).

14) R. H. Metcalf and R. H. Deibel, ibid., 99, 674 (1969). 